\title{
Endothelial $\mathrm{ET}_{\mathrm{B}}$ Limits Vascular Remodelling and Development of Pulmonary Hypertension during Hypoxia
}

\author{
N.F. Kelland ${ }^{a} \quad$ A.J. Bagnall ${ }^{a} \quad$ I. Morecroft ${ }^{b} \quad$ F.H. Gulliver-Sloan ${ }^{a} \quad$ Y. Dempsie ${ }^{b}$ \\ M. Nilsen ${ }^{b} \quad$ M. Yanagisawa ${ }^{c} \quad$ M.R. MacLean ${ }^{b} \quad$ Y.V. Kotelevtsev ${ }^{a} \quad$ D.J. Webb ${ }^{a}$ \\ ${ }^{a}$ Centre for Cardiovascular Science, University of Edinburgh, Edinburgh, and ${ }^{\mathrm{b}}$ Integrative and Systems Biology,



\section{Key Words}

$\mathrm{ET}_{\mathrm{B}}$ receptor $\cdot$ Knockout $\cdot$ Endothelin $\cdot$ Pulmonary

hypertension

\begin{abstract}
Background: We hypothesised that the potential protective effects of endothelial $\mathrm{ET}_{\mathrm{B}}$ are important in limiting pulmonary vascular muscularisation, vasoconstriction and the development of pulmonary arterial hypertension in response to hypoxia. Methods: EC-specific $\mathrm{ET}_{\mathrm{B}}$ knockout mice (EC $\left.\mathrm{ET}_{\mathrm{B}}{ }^{-l-}\right)$ and control mice $\left(\mathrm{ET}_{\mathrm{B}}^{\mathrm{f} / \mathrm{f}}\right)$ were subjected to hypobaric hypoxic $\left(10 \% \mathrm{FiO}_{2}\right)$ or normoxic conditions for 14 days before assessment of right ventricular pressure and pulmonary vascular morphology and function. Results: During normoxia, no difference in right ventricular pressure was detected between $\mathrm{EC} \mathrm{ET}_{\mathrm{B}}{ }^{-/-}(23.7 \pm 1.7 \mathrm{~mm} \mathrm{Hg})$ and $\mathrm{ET}_{\mathrm{B}}^{\mathrm{f} / \mathrm{f}}$ mice $(20.2 \pm$ $1.5 \mathrm{~mm} \mathrm{Hg}$ ). Hypoxia induced an exaggerated increase in right ventricular pressure in $\mathrm{EC} \mathrm{ET}_{\mathrm{B}}{ }^{-/-}$mice $(34.4 \pm 1.2 \mathrm{~mm}$ $\mathrm{Hg}$ vs. $24.6 \pm 1.4 \mathrm{~mm} \mathrm{Hg}$ ), accompanied by an increase in right ventricular mass. No effect was observed in $\mathrm{ET}_{\mathrm{B}}{ }^{\mathrm{f} / \mathrm{f}}$ mice. Endothelin-1 constricted pulmonary arteries from both groups, although maximum response was similar irrespective of inspired oxygen or genotype. Hypoxia increased the percentage of muscularised vessels in both groups of mice, but the percentage increase was significantly greater in EC
\end{abstract}

$\mathrm{ET}_{\mathrm{B}}{ }^{-/-}$mice. Conclusions: The potential protective effects of endothelial $\mathrm{ET}_{\mathrm{B}}$ are important in limiting pulmonary vascular muscularisation and the development of pulmonary arterial hypertension in response to hypoxia.

Copyright $\odot 2009$ S. Karger AG, Basel

\section{Introduction}

Pulmonary arterial hypertension (PAH) is a progressive condition involving small pulmonary arteries (PAs) characterised by a sustained increase in pulmonary vascular resistance and vascular remodelling leading ultimately to right ventricular failure and premature death [1]. Several lines of evidence implicate endothelin-1 (ET1) in the aetiology and progression of PAH. First, ET-1 is a potent vasoconstrictor and mitogen [2]. Second, plasma concentration of ET-1 correlates with severity of PAH in animal models [3-5] and patients [6], and third, non-selective and selective endothelin A receptor antagonists improve symptoms and slow the progression of PAH [7, 8]. The lung is an important site of ET-1 production with a concentration of ET-1 five times greater than that seen in other organs [9]. Endothelin B receptor $\left(\mathrm{ET}_{\mathrm{B}}\right) \mathrm{mRNA}$ is expressed abundantly in the lung [10], particularly in distal segments of the pulmonary vascular tree [11], where

Dr. Alan Bagnal

Centre for Cardiovascular Science, University of Edinburgh

Queen's Medical Research Institute

47 Little France Crescent, Edinburgh EH16 4TJ (UK)

Tel. +44 131242 9236, Fax +44 709286 9504, E-Mail alan.bagnall@ed.ac.uk 
it is found in the endothelium and media of pulmonary blood vessels as well as in bronchioles and alveoli.

In contrast, endothelin A receptors $\left(\mathrm{ET}_{\mathrm{A}}\right)$ are localised to the media of large proximal PAs and veins with relatively little expression in distal arterioles [11-13]. Hypoxia increases the expression of ET-1, $\mathrm{ET}_{\mathrm{A}}$ and $\mathrm{ET}_{\mathrm{B}}$ throughout the rat lung $[10,12]$ with histological evidence to suggest a preferential increase in endothelial cell (EC) $\mathrm{ET}_{\mathrm{B}}$ expression in distal segments [13]. $\mathrm{EC} \mathrm{ET}_{\mathrm{B}}$ elicit vasodilatation and anti-mitogenic effects through the release of nitric oxide $(\mathrm{NO})$ and/or prostaglandin $\mathrm{I}_{2}\left(\mathrm{PGI}_{2}\right)[14,15]$. Increased ET-1/EC $\mathrm{ET}_{\mathrm{B}}$-mediated vasodilatation has thus been hypothesised to protect against hypoxia-induced vasoconstriction [13], and studies in rats suggest that $\mathrm{ET}_{\mathrm{B}}$ deficiency exacerbates monocrotaline- [16] and hypoxiainduced PAH [17]. Pulmonary ET $_{\mathrm{B}}$ also clear ET-1 from the plasma [18], further limiting $\mathrm{ET}_{\mathrm{A}}$-mediated vasoconstrictor and mitogenic effects.

Vascular smooth muscle cell (VSMC) $\mathrm{ET}_{\mathrm{B}}$ mediate vasoconstriction in humans [19]. In hypoxic rat models [20] and sheep models of embolism-induced $\mathrm{PAH}$ and $\mathrm{PAH}$ secondary to aortopulmonary shunting, there is evidence of increased VSMC $\mathrm{ET}_{\mathrm{B}}$-mediated vasoconstriction [21, 22]. Activation of $\mathrm{ET}_{\mathrm{A}}$ and $\mathrm{ET}_{\mathrm{B}}$ on VSMC by ET-1 also promotes cellular hypertrophy [11] and hence may promote the progression of $\mathrm{PAH}$ through muscularisation of small pulmonary arterioles. Thus, with respect to the development of $\mathrm{PAH}$, pulmonary $\mathrm{ET}_{\mathrm{B}}$ have the potential to elicit both protective and detrimental effects. Study of the interplay between EC and VSMC ET ${ }_{\mathrm{B}}$ is likely to increase our mechanistic understanding of the role of the endothelin system in the pathogenesis of PAH. We have previously generated EC-specific $\mathrm{ET}_{\mathrm{B}}$ knockout $(\mathrm{KO})$ mice that exhibit endothelial dysfunction in the absence of systemic hypertension, with evidence of impaired endogenous NO release and increased plasma ET-1 [23]. Otherwise, they have normal feeding and growth rates, exhibit normal behaviour and are healthy. Here we have used this model to determine whether the potential protective effects of $\mathrm{ECET}_{\mathrm{B}}$ are important in limiting pulmonary vascular muscularisation and the development of PAH during hypoxia.

\section{Methods}

\section{Experimental Animals}

Mice featuring selective $\mathrm{KO}$ of $\mathrm{EC} \mathrm{ET}_{\mathrm{B}}$ were generated using a Cre-LoxP approach as previously described [23]. Briefly, mice with loxP sites flanking exons 3 and 4 of the $\mathrm{ET}_{\mathrm{B}}$ gene ('floxed' mice, $\left.\mathrm{ET}_{\mathrm{B}}{ }^{\mathrm{f} / \mathrm{f}}\right)$ were crossed with mice expressing a Cre recombi- nase transgene in an EC-restricted pattern (WW/Tie2-Cre) [24] to produce $\mathrm{EC}$-specific $\mathrm{ET}_{\mathrm{B}} \mathrm{KO}$ mice $\left(\mathrm{EC} \mathrm{ET}_{\mathrm{B}}{ }^{-l}\right)$. Genotyping to identify the flox and recombined alleles was performed by Southern blot and by PCR using primers amplifying a sequence spanning the $3^{\prime}$ and $5^{\prime}$ loxP sites (forward primer: TCA GTT GTA ATG AGA CAC AGA C; reverse primer: AGC CAT AAA GTC ACA GCC ATT C). The Tie2-Cre transgene was detected by PCR as described [24]. Male mice aged 8-12 weeks (weight 25-35 g) were studied and $\mathrm{EC} \mathrm{ET}_{\mathrm{B}}{ }^{-/-}$mice compared with $\mathrm{ET}_{\mathrm{B}}{ }^{\mathrm{f} / \mathrm{f}}$ control mice in all experiments. The genetic background of each group was 129/Ola; BKW; C57Bl/6; SJLF . All procedures were carried out with the approval of the University of Glasgow and University of Edinburgh Local Ethical Review Committees, under Home Office Project and Personal Licence authority.

\section{Hypobaric Chambers}

$\mathrm{EC} \mathrm{ET}_{\mathrm{B}}{ }^{-1-}$ mice and control mice (10 animals/group) were exposed to hypobaric hypoxic conditions for 14 days by housing them in a specially designed hypobaric chamber, as previously described [20]. The chamber was depressurised over the course of 2 days to $550 \mathrm{mbar}$ [ $55 \mathrm{kPa}$ or $413 \mathrm{~mm} \mathrm{Hg}$, equivalent to $\mathrm{FiO}_{2}$ (percentage oxygen in inspired air) $=10 \%]$. A further 10 age-matched mice of each genotype were maintained in the same room breathing air at atmospheric pressure $\left(\mathrm{FiO}_{2}=21 \%\right)$. All mice were allowed free access to standard rodent chow and water throughout the study and kept under 12-hour light/dark cycles.

\section{Haemodynamic Studies}

Anaesthesia was induced with $2-4 \%$ halothane and maintained with $1.5 \%$ halothane using a mix (1 part:3 parts) of $\mathrm{NO}_{2}$ and high-flow $\mathrm{O}_{2}$. Pressure and heart rate measurements were performed and analysed as previously described [25]. Systemic arterial pressure was measured via a cannula (Portex, $0.75 \mathrm{~mm}$ $\mathrm{OD}$ ) inserted into the right carotid artery. A 25-gauge needle was advanced into the right ventricle (RV) via a transdiaphragmatic approach for measurement of right ventricular pressure (RVP). At the end of the experiment, mice were killed by lethal overdose of halothane. The heart was removed, blotted dry of blood and weighed. The right lung was placed in formal saline (1 part $37 \%$ formaline:9 parts $0.9 \%$ saline) for histology and third-order PAs dissected from the left lung for wire myography experiments.

\section{Assessment of RV Hypertrophy}

Hearts were dissected clean of pericardial tissue, blotted dry and the atria and great vessels removed to the plane of the atrioventricular valves. The RV free wall was dissected free from the left ventricle and septum $(\mathrm{LV}+\mathrm{S})$ and weighed. The ratios of RV/ body weight (BW), RV/(LV+S) and RV/total ventricles (TV) were calculated [25].

\section{Lung Histology}

The right lung was embedded in paraffin and $10-\mu \mathrm{m}$ sections stained with Miller's elastin stain [26] and with picrosirius red for collagen [27]. Sections were microscopically assessed for muscularisation of small PAs (25-100 $\mu$ m external diameter) associated with an airway distal to the respiratory bronchiole. Arteries were considered muscularised if they possessed a distinct double-elastic lamina visible for at least half the diameter of the vessel in cross-section (fig. 2). The percentage of vessels containing double-elastic lamina was calculated as the number of muscularised 



Fig. 1. a Systolic right ventricular pressure of anaesthetised $\mathrm{ET}_{\mathrm{B}}{ }^{\mathrm{f} / \mathrm{f}}$ and $\mathrm{EC} \mathrm{ET}_{\mathrm{B}}{ }^{-l-}$ mice $(\mathrm{n}=10)$. $\mathbf{b}$ Percentage of muscularised vessels in lungs from $\mathrm{EC} \mathrm{ET}_{\mathrm{B}}{ }^{-1-}$ mice and $\mathrm{ET}_{\mathrm{B}}{ }^{\mathrm{f} / \mathrm{f}}$ controls $(\mathrm{n}=6)$ following 14 days of normoxia or hypobaric hypoxia. c Right ventricular hypertrophy, as determined by the ratio $\mathrm{RV} /(\mathrm{LV}+\mathrm{S})$, of $\mathrm{ET}_{\mathrm{B}}^{\mathrm{f} / \mathrm{f}}$ and $\mathrm{EC} \mathrm{ET}_{\mathrm{B}}{ }^{-/-}$mice $(\mathrm{n}=10)$.

vessels/total number of vessels counted per section $\times 100$. Three sections from each right lung were assessed for every mouse. A total of 6 mice per group were analysed.

\section{In vitro Wire Myography}

Third-order PAs (first interlobar; approx. $300 \mu \mathrm{m}$ internal diameter) from the left lung were cut to yield two $2 \mathrm{~mm}$-long segments, which were then mounted onto a wire myograph. Vessels were bathed in Krebs buffer solution (118.4 mM NaCl; $25 \mathrm{~mm}$ $\mathrm{NaHCO}_{3} ; 4.7 \mathrm{~mm} \mathrm{KCl} ; 1.2 \mathrm{mM} \mathrm{KH}_{2} \mathrm{PO}_{4} ; 0.6 \mathrm{mM} \mathrm{MgSO}_{4} ; 2.5 \mathrm{~mm}$ $\mathrm{CaCl}_{2} ; 11 \mathrm{mM}$ glucose; $\mathrm{pH} 7.4$ ) at $37^{\circ} \mathrm{C}$ and constantly bubbled with $16 \% \mathrm{O}_{2} / 5 \% \mathrm{CO}_{2}$. Tension was applied to give transmural pressures equivalent to $12-14 \mathrm{~mm} \mathrm{Hg}$ for controls and 30-33 $\mathrm{mm} \mathrm{Hg}$ for hypoxic animals. These pressures are similar to those experienced by pulmonary vessels in vivo in rodents under similar hypobaric conditions [28, 29]. Following equilibration, $\mathrm{PA}$ rings were constricted twice with $50 \mathrm{mM} \mathrm{KCl}$ solution. Cumulative concentration-response curves were constructed for ET-1 $\left(10^{-15}\right.$ to $\left.10^{-7} \mathrm{M}\right)$ following a 30 -min incubation with $100 \mu \mathrm{M}$ N-nitro-L-arginine methylester (L-NAME) or vehicle. All responses were expressed as a percentage of the maximal $\mathrm{KCl}$-induced constriction.

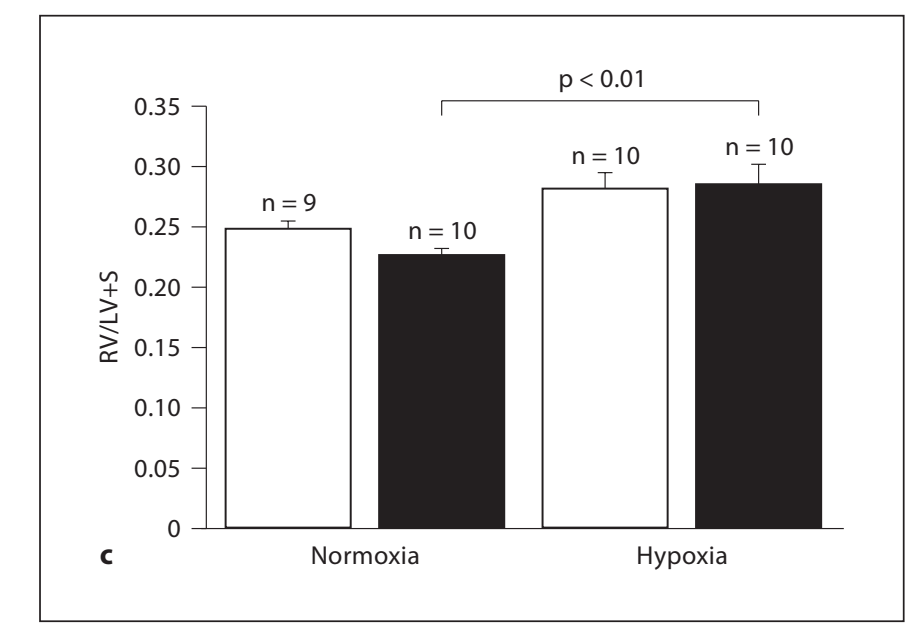

Drugs

Halothane, formalin and L-NAME were all purchased from Sigma-Aldrich (Gillingham, UK). ET-1 was purchased from Merck Chemicals Limited (Nottingham, UK).

\section{Data Analysis and Statistical Procedures}

Data are expressed as means \pm SEM. Statistical comparisons were made by two-way ANOVA. When significance was attained $(\mathrm{p}<0.05)$, differences were established using the Bonferroni multiple comparison test. In the myography studies, $\mathrm{pEC}_{50}$ values were calculated from concentration-response curves by graphical interpolation (GraphPad Prism 4.0).

\section{Results}

\section{Haemodynamic Studies}

Systemic mean arterial blood pressure was not significantly different between $\mathrm{EC} \mathrm{ET}_{\mathrm{B}}{ }^{-1-}$ mice and controls under either normoxic $\left(\mathrm{ET}_{\mathrm{B}}^{\mathrm{f} / \mathrm{f}} 99 \pm 4 \mathrm{~mm} \mathrm{Hg} ; \mathrm{EC} \mathrm{ET}_{\mathrm{B}}{ }^{-/-}\right.$ 

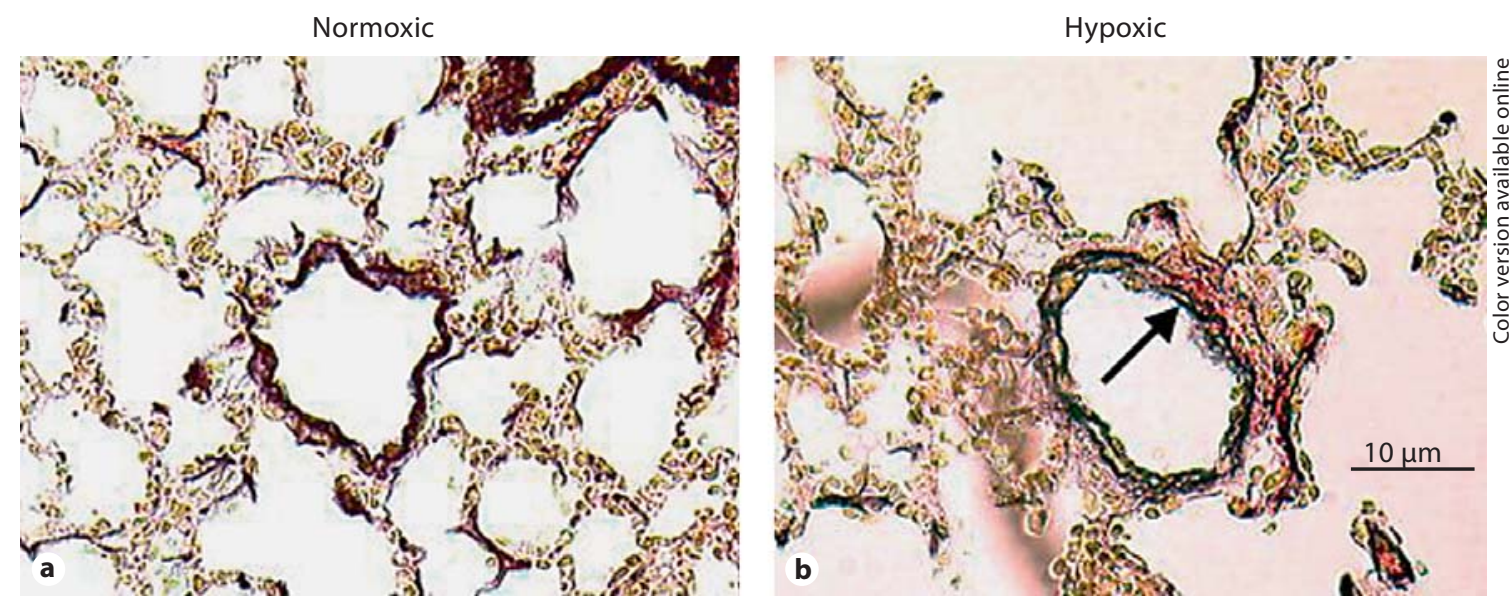

Fig. 2. Representative sections illustrating normal murine small PAs under normoxic conditions (a) and muscularised arteries with a double elastic lamina (b, arrow) that develop following 14 days of hypobaric hypoxia. The proportion of muscularised to normal vessels in response to hypoxia was greater in $\mathrm{EC}_{\mathrm{ET}_{\mathrm{B}}}{ }^{-1}$ mice than in $\mathrm{ET}_{\mathrm{B}}^{\mathrm{f} / \mathrm{f}}$ mice. Sections are stained with Miller's elastin stain and picrosirius red collagen stain.

Table 1. Indices of right ventricular hypertrophy in $\mathrm{ET}_{\mathrm{B}}^{\mathrm{f} / \mathrm{f}}$ and $\mathrm{EC} \mathrm{ET}_{\mathrm{B}}{ }^{-/-}$mice under normoxic conditions or following 14 days of hypobaric hypoxia

\begin{tabular}{lllllllll}
\hline & $\mathrm{ET}_{\mathrm{B}}^{\mathrm{f} / \mathrm{f}}$ & & & & $\mathrm{EC} \mathrm{ET}_{\mathrm{B}}{ }^{-/-}$ & \\
\cline { 2 - 3 } & $\mathrm{RV} /(\mathrm{LV}+\mathrm{S})$ & $\mathrm{RV} / \mathrm{TV}$ & $\mathrm{RV} / \mathrm{BW}$ & & $\mathrm{RV} /(\mathrm{LV}+\mathrm{S})$ & $\mathrm{RV} / \mathrm{TV}$ & $\mathrm{RV} / \mathrm{BW}$ \\
\hline Normoxic & $0.25 \pm 0.009$ & $0.20 \pm 0.006$ & $0.80 \pm 0.065$ & & $0.22 \pm 0.009$ & $0.18 \pm 0.006$ & $0.75 \pm 0.047$ \\
Hypoxic & $0.28 \pm 0.012$ & $0.22 \pm 0.007$ & $1.03 \pm 0.083^{*}$ & & $0.29 \pm 0.017^{*}$ & $0.22 \pm 0.010^{*}$ & $0.98 \pm 0.045^{*}$ \\
\hline
\end{tabular}

Values are means \pm SEM (10 animals/group). ${ }^{*} \mathrm{p}<0.05$ for comparison between normoxic and hypoxic animals within each genotype.

$101 \pm 4 \mathrm{~mm} \mathrm{Hg})$ or hypoxic conditions $\left(\mathrm{ET}_{\mathrm{B}}^{\mathrm{f} / \mathrm{f}} 93 \pm\right.$ $4 \mathrm{~mm} \mathrm{Hg} ; \mathrm{EC} \mathrm{ET}_{\mathrm{B}}{ }^{-l-} 103 \pm 4 \mathrm{~mm} \mathrm{Hg}$ ), as previously reported [23]. No difference in heart rate was observed. Although systolic RVP was similar between genotypes under normoxic conditions, following 2 weeks of hypoxia, systolic RVP in $\mathrm{EC} \mathrm{ET}_{\mathrm{B}}{ }^{-/-}$mice was significantly elevated compared to hypoxic $\mathrm{ET}_{\mathrm{B}}{ }^{\mathrm{f} / \mathrm{f}}$ controls (fig. 1a).

\section{Right Ventricular Hypertrophy}

Relative right ventricular mass, as measured by RV/ $(\mathrm{LV}+\mathrm{S})$ and $\mathrm{RV} / \mathrm{TV}$ ratios, tended to be lower in normoxic $\mathrm{EC}_{\mathrm{ET}_{\mathrm{B}}}{ }^{-1-}$ mice compared to normoxic $\mathrm{ET}_{\mathrm{B}}{ }^{\mathrm{f} / \mathrm{f}}$ controls. Body weight fell by approximately $3.4 \mathrm{~g}$ in both genotypes following 2 weeks of hypoxia. Both genotypes demonstrated a significant increase in RV/BW ratio when exposed to hypoxia. However, only hypoxic $\mathrm{EC} \mathrm{ET}_{\mathrm{B}}{ }^{-/-}$mice demonstrated a significant increase in $\mathrm{RV} /(\mathrm{LV}+\mathrm{S})$ ratio and $\mathrm{RV} / \mathrm{TV}$, suggesting a preferential increase in $\mathrm{RV}$ mass (fig. 1c; table 1).

\section{Vascular Morphology}

Under normoxic conditions, the percentage of muscularised vessels was similar in $\mathrm{EC} \mathrm{ET}_{\mathrm{B}}{ }^{-/-}$and $\mathrm{ET}_{\mathrm{B}}{ }^{\mathrm{f} / \mathrm{f}}$ mice. Following hypoxia, muscularisation was observed in a significantly greater proportion of vessels from EC $\mathrm{ET}_{\mathrm{B}}{ }^{-/-}$mice compared to controls (fig. 1b, 2).

\section{Myography}

Neither genotype nor $\mathrm{FiO}_{2}$ influenced the $\mathrm{E}_{\max }$ or $\mathrm{pEC}_{50}$ of PAs to ET-1 (table 1). Treatment with L-NAME did not significantly alter the maximum constriction or tissue sensitivity to ET-1 in either genotype (table 2). 
Table 2. Potency and maximum effect of ET-1 in PA rings from $\mathrm{EC} \mathrm{ET}_{\mathrm{B}}{ }^{-/-}$and $\mathrm{ET}_{\mathrm{B}} \mathrm{f}^{\mathrm{ff}}$ mice

\begin{tabular}{|c|c|c|c|c|c|c|}
\hline & \multicolumn{3}{|l|}{$\mathrm{ET}_{\mathrm{B}}^{\mathrm{f} / \mathrm{f}}$} & \multicolumn{3}{|l|}{$\mathrm{EC} \mathrm{ET}_{\mathrm{B}}{ }^{-/-}$} \\
\hline & $\mathrm{pEC}_{50}$ & $\mathrm{E}_{\max }$ & $\mathrm{n}$ & $\mathrm{pEC}_{50}$ & $\mathrm{E}_{\max }$ & $\mathrm{n}$ \\
\hline Normoxic & $9.2 \pm 0.1$ & $121.9 \pm 4.8$ & 7 & $8.8 \pm 0.1$ & $109.7 \pm 7.2$ & 7 \\
\hline Hypoxic & $10.1 \pm 0.2$ & $116.8 \pm 9.0$ & 5 & $9.6 \pm 0.1$ & $125.4 \pm 5.5$ & 5 \\
\hline Normoxic + L-NAME & $9.7 \pm 0.2$ & $126.3 \pm 3.4$ & 7 & $9.1 \pm 0.9$ & $120.2 \pm 5.0$ & 6 \\
\hline Hypoxic + L-NAME & $10.1 \pm 0.2$ & $124.3 \pm 7.1$ & 6 & $10.5 \pm 0.1$ & $143.0 \pm 6.0$ & 9 \\
\hline
\end{tabular}

$\mathrm{E}_{\max }$ is expressed as a percentage of the maximal contractile response to $50 \mathrm{mM} \mathrm{KCl}$ solution.

\section{Discussion}

This study demonstrates that in response to 14 days of hypobaric hypoxia, selective loss of $\mathrm{EC}_{\mathrm{ET}} \mathrm{B}$ results in an exaggerated increase in systolic RVP, an increase in RV mass and an increase in the proportion of muscularised small PAs. However, we did not observe systemic hypertension, implying a selective effect of loss of $\mathrm{EC} \mathrm{ET}_{\mathrm{B}}$ in the pulmonary vasculature.

After 14 days of hypoxia, we observed no increase in systolic RVP in control $\mathrm{ET}_{\mathrm{B}} \mathrm{f} / \mathrm{f}$ mice that were of the same genetic background as $\mathrm{EC} \mathrm{ET}_{\mathrm{B}}{ }^{-1-}$ mice. The development of hypoxia-induced PAH differs between mice of different strains, although even relatively resistant mice have been shown to develop raised systolic RVP after 4 weeks of hypoxia [30]. It is likely that our control $\mathrm{ET}_{\mathrm{B}}^{\mathrm{f} / \mathrm{f}}$ mice would have developed elevated systolic RVP after such a prolonged period of hypoxic exposure. However, we can conclude that loss of $\mathrm{EC} \mathrm{ET}_{\mathrm{B}}$ either accelerated the increase in systolic RVP in this strain or enabled PAH to develop in a strain resistant to the effects of hypoxia.

There are several possible mechanisms that may underlie the exaggerated increase in RVP in $\mathrm{EC} \mathrm{ET}_{\mathrm{B}}{ }^{-/-}$mice. First, $\mathrm{EC} \mathrm{ET}_{\mathrm{B}}$ vasodilator pathways are likely to be an important protective mechanism that limits the development of PAH during chronic hypoxia. In vitro studies of rat pulmonary microvascular ECs demonstrate that an increase in shear stress increases $\mathrm{ET}_{\mathrm{B}}$ expression and enhances ET-1-mediated $\mathrm{ET}_{\mathrm{B}}$-dependent eNOS activation [31]. Lungs from rescued $\mathrm{ET}_{\mathrm{B}}$-deficient rats also demonstrate an exaggerated pressor response to ET-1 [32], due in part to reduced $\mathrm{NO}$ and $\mathrm{PGI}_{2}$ production [17]. Studies of eNOS over-expressing [33] and eNOS KO mice [34, 35] have revealed that a reduction in EC-derived NO increases vascular tone and muscularisation of PAs. We have previously reported endothelial dysfunction with decreased NO bioavailability in the absence of systemic hypertension in the aortae of $\mathrm{EC} \mathrm{ET}_{\mathrm{B}}{ }^{-/-}$mice [23]. Thus, impaired $\mathrm{EC} \mathrm{ET}_{\mathrm{B}}$-mediated $\mathrm{NO} / \mathrm{PGI}_{2}$ release from pulmonary resistance vessels during hypoxia may have contributed to the development of PAH. We also observed an exaggerated increase in the number of muscularised small pulmonary vessels in $\mathrm{EC} \mathrm{ET}_{\mathrm{B}}{ }^{-1-}$ mice following hypoxia. Thus, loss of $\mathrm{ET}_{\mathrm{B}}$-mediated $\mathrm{NO}$ release may also have had a permissive effect on hypoxia-induced vessel muscularisation.

Second, $\mathrm{EC}_{\mathrm{ET}_{\mathrm{B}}}^{-{ }^{-1}}$ mice have elevated plasma ET-1 concentration [23] that may directly exert pressor and mitogenic actions to further promote the development of $\mathrm{PAH}$. Studies in our laboratory demonstrate that clearance of ET-1 is impaired and plasma ET-1 increased approximately 4 -fold in these mice [23]. Increased plasma ET-1 has also been reported in patients with PAH $[6,36$, 37], though this may reflect increased production rather than impaired pulmonary clearance [38]. Loss of $\mathrm{ET}_{\mathrm{B}}$ signalling has also been reported to increase ECE-1 mRNA expression [39], which may further contribute to an increase in ET-1. However, the limited experimental evidence available suggests that an isolated increase in ET-1 is insufficient to cause PAH. Under normoxic conditions, rats chronically infused with ET-1 by subcutaneous pump do not develop raised systolic RVP [40]. Similarly, transgenic mice that over-express preproET-1 have elevated plasma ET-1, exhibit pulmonary inflammation and fibrosis, but do not develop PAH, even when exposed to mild hypoxia $\left(\mathrm{FiO}_{2} 16 \%\right)$ [41]. Thus, although an increase in ET-1 may contribute to many of the pathological processes associated with $\mathrm{PAH}$, concomitant loss of $\mathrm{NO} /$ $\mathrm{PGI}_{2}$-mediated vasodilator pathways is likely to be necessary for PAH to develop. 
Although expression of Tie2 was thought to be exclusively restricted to ECs, Tie2-positive monocytes have now been identified $[42,43]$. Thus, Cre-Lox-mediated ablation of the $\mathrm{ET}_{\mathrm{B}}$ gene may have occurred in such inflammatory cells, as well as in ECs, potentially complicating the interpretation of the phenotype of the EC $\mathrm{ET}_{\mathrm{B}}{ }^{-/-}$mice. Although no inflammatory infiltrate was seen in the lung sections from the hypoxic $\mathrm{EC} \mathrm{ET}_{\mathrm{B}}{ }^{-/}$ mice, further studies to clarify the role of such macrophages in the development of PAH are required.

We found no difference in the maximal response or sensitivity of 3rd order PAs to ET-1 in $\mathrm{EC}_{\mathrm{ET}_{\mathrm{B}}}{ }^{-/-}$mice. The absence of any change in ET-1-mediated constriction following L-NAME suggests that NO does not contribute significantly to vascular tone in vessels of this size. This finding does not necessarily contradict our hypothesis that loss of $\mathrm{ET}_{\mathrm{B}}$-mediated $\mathrm{NO}$ release contributed to hypoxia-induced $\mathrm{PAH}$ in $\mathrm{EC} \mathrm{ET}_{\mathrm{B}}{ }^{-1-}$ mice. Indeed, studies of rat intrapulmonary arteries following $4 \mathrm{~h}$ of either normoxia or hypoxia found similar results, demonstrating no effect of nitro-L-arginine on $\mathrm{ET}_{\mathrm{B}}$-mediated contraction [44]. In contrast, chronic in vivo telemetric measurements of PAP demonstrate that L-NAME acutely increases PAP in the mouse [45], suggesting that NO is an important determinant of PAP in this species. Thus, hypoxia-induced $\mathrm{PAH}$ in $\mathrm{EC} \mathrm{ET}_{\mathrm{B}}{ }^{-/-}$mice may be due to an increase in the tone of resistance arterioles smaller than those possible to study in myography experiments.
Several studies in mice report weight loss following exposure to hypoxia, an effect that is incompletely understood but may involve altered expression of genes regulated by hypoxia-inducible factor $\alpha$ [46]. However, we saw no difference in weight loss (approx. $3.4 \mathrm{~g}$ ) between controls and $\mathrm{EC} \mathrm{ET}_{\mathrm{B}}{ }^{-1-}$ mice. Although weight loss contributed to the increase in RV/BW ratio in both groups, we only observed an absolute increase in RV mass [as determined by $\mathrm{RV} /(\mathrm{LV}+\mathrm{S})$ ratio and $\mathrm{RV} / \mathrm{TV}$ ratio] in $\mathrm{EC}$ $\mathrm{ET}_{\mathrm{B}}{ }^{-/-}$mice. This increase is, therefore, likely to reflect a true RV hypertrophic response to the increased PAP in $\mathrm{EC} \mathrm{ET}_{\mathrm{B}}{ }^{-/-}$mice, rather than any disproportionate weight loss in KOs.

In conclusion, this study indicates that $\mathrm{EC} \mathrm{ET}_{\mathrm{B}}$ play an important protective role during prolonged hypoxia that limits vascular remodelling and the development of pulmonary hypertension.

\section{Acknowledgements}

N.F.K. was a British Heart Foundation Junior Research Fellow (FS/03/006/15198). A.J.B. was funded by a Wellcome Trust Clinical Research Fellowship (055891/Z/98/Z/DG/MH/fh). This work was supported by the Wellcome Trust Cardiovascular Research Initiative (Grant No. 065901/Z/01/Z\&A). Y.D. and I.M. were funded by the BBSRC and BHF, respectively.

\section{References}

1 Humbert M, Barst RJ, Robbins IM, Channick RN, Galie N, Boonstra A, Rubin LJ, Horn EM, Manes A, Simonneau G: Combination of bosentan with epoprostenol in pulmonary arterial hypertension: BREATHE-2. Eur Respir J 2004;24:353-359.

-2 Yanagisawa M, Kurihara H, Kimura S, Tomobe Y, Kobayashi M, Mitsui Y, Yazaki Y, Goto K, Masaki T: A novel potent vasoconstrictor peptide produced by vascular endothelial cells. Nature 1988;332:411-415.

-3 Stelzner TJ, O'Brien RF, Yanagisawa M, Sakurai T, Sato K, Webb S, Zamora M, McMurtry IF, Fisher JH: Increased lung endothelin-1 production in rats with idiopathic pulmonary hypertension. Am J Physiol 1992;262:L614-L620.

4 Frasch HF, Marshall C, Marshall BE: Endothelin-1 is elevated in monocrotaline pulmonary hypertension. Am J Physiol 1999;276: L304-L310.
5 Nakanishi K, Tajima F, Nakata Y, Osada H, Tachibana S, Kawai T, Torikata C, Suga T, Takishima K, Aurues T, Ikeda T: Expression of endothelin-1 in rats developing hypobaric hypoxia-induced pulmonary hypertension. Lab Invest 1999;79:1347-1357.

-6 Cacoub P, Dorent R, Nataf P, Carayon A, Riquet M, Noe E, Piette JC, Godeau P, Gandjbakhch I: Endothelin-1 in the lungs of patients with pulmonary hypertension. Cardiovasc Res 1997;33:196-200.

$\checkmark 7$ Rubin LJ, Badesch DB, Barst RJ, Galie N, Black CM, Keogh A, Pulido T, Frost A, Roux S, Leconte I, Landzberg M, Simonneau G: Bosentan therapy for pulmonary arterial hypertension. N Engl J Med 2002;346:896903.

$\checkmark 8$ Barst RJ, Langleben D, Badesch D, Frost A, Lawrence EC, Shapiro S, Naeije R, Galie N: Treatment of pulmonary arterial hypertension with the selective endothelin-A receptor antagonist sitaxsentan. J Am Coll Cardiol 2006;47:2049-2056.
$>9$ Firth JD, Ratcliffe PJ: Organ distribution of the three rat endothelin messenger RNAs and the effects of ischemia on renal gene expression. J Clin Invest 1992;90:1023-1031.

10 Li H, Chen SJ, Chen YF, Meng QC, Durand J, Oparil S, Elton TS: Enhanced endothelin-1 and endothelin receptor gene expression in chronic hypoxia. J Appl Physiol 1994;77: 1451-1459.

11 Davie N, Haleen SJ, Upton PD, Polak JM, Yacoub MH, Morrell NW, Wharton J: $\mathrm{ET}_{\mathrm{A}}$ and $\mathrm{ET}_{\mathrm{B}}$ receptors modulate the proliferation of human pulmonary artery smooth muscle cells. Am J Respir Crit Care Med 2002;165: 398-405.

12 Takahashi H, Soma S, Muramatsu M, Oka M, Fukuchi Y: Upregulation of ET-1 and its receptors and remodeling in small pulmonary veins under hypoxic conditions. Am J Physiol Lung Cell Mol Physiol 2001;280: L1104-L1114. 
13 Soma S, Takahashi H, Muramatsu M, Oka M, Fukuchi Y: Localization and distribution of endothelin receptor subtypes in pulmonary vasculature of normal and hypoxia-exposed rats. Am J Respir Cell Mol Biol 1999; 20:620-630.

- 14 de Nucci G, Thomas R, D'Orleans-Juste P, Antunes E, Walder C, Warner TD, Vane JR: Pressor effects of circulating endothelin are limited by its removal in the pulmonary circulation and by the release of prostacyclin and endothelium-derived relaxing factor. Proc Natl Acad Sci USA 1988;85:97979800.

-15 Takayanagi R, Kitazumi K, Takasaki C Ohnaka K, Aimoto S, Tasaka K, Ohashi M, Nawata H: Presence of non-selective type of endothelin receptor on vascular endothelium and its linkage to vasodilation. FEBS Lett 1991;282:103-106.

16 Nishida M, Okada Y, Akiyoshi K, Eshiro K, Takoaka M, Gariepy CE, Yanagisawa M, Matsumura Y: Role of endothelin ETB receptor in the pathogenesis of monocrotaline-induced pulmonary hypertension in rats. Eur J Pharmacol 2004;496:159-165.

$\checkmark 17$ Ivy DD, Yanagisawa M, Gariepy CE, Gebb SA, Colvin KL, McMurtry IF: Exaggerated hypoxic pulmonary hypertension in endothelin B receptor-deficient rats. Am J Physiol Lung Cell Mol Physiol 2002;282:L703-L712.

-18 Dupuis J, Goresky CA, Fournier A: Pulmonary clearance of circulating endothelin-1 in dogs in vivo: exclusive role of ETB receptors. J Appl Physiol 1996;81:1510-1515.

$\checkmark 19$ McCulloch KM, Docherty CC, Morecroft I, MacLean MR: Endothelin B receptor-mediated contraction in human pulmonary resistance arteries. Br J Pharmacol 1996;119: $1125-1130$.

-20 McCulloch KM, Docherty C, MacLean MR: Endothelin receptors mediating contraction of rat and human pulmonary resistance arteries: effect of chronic hypoxia in the rat. $\mathrm{Br}$ J Pharmacol 1998;123:1621-1630.

-21 Balyakina EV, Chen D, Lawrence ML, Manning S, Parker RE, Shappell SB, Meyrick B: ET-1 receptor gene expression and distribution in L1 and L2 cells from hypertensive sheep pulmonary artery. Am J Physiol Lung Cell Mol Physiol 2002;283:L42-L51.

22 Black SM, Mata-Greenwood E, Dettman RW, Ovadia B, Fitzgerald RK, Reinhartz O, Thelitz S, Steinhorn RH, Gerrets R, Hendricks-Munoz K, Ross GA, Bekker JM, Johengen MJ, Fineman JR: Emergence of smooth muscle cell endothelin B-mediated vasoconstriction in lambs with experimental congenital heart disease and increased pulmonary blood flow. Circulation 2003; 108:1646-1654

-23 Bagnall AJ, Kelland NF, Gulliver-Sloan F, Davenport AP, Gray GA, Yanagisawa M, Webb DJ, Kotelevtsev YV: Deletion of endothelial cell endothelin B receptors does not affect blood pressure or sensitivity to salt. Hypertension 2006;48:286-293.
24 Kisanuki YY, Hammer RE, Miyazaki J, Williams SC, Richardson JA, Yanagisawa M: Tie2-Cre transgenic mice: a new model for endothelial cell-lineage analysis in vivo. Dev Biol 2001;230:230-242.

25 Keegan A, Morecroft I, Smillie D, Hicks MN MacLean MR: Contribution of the 5- $\mathrm{HT}_{1 \mathrm{~B}}$ receptor to hypoxia-induced pulmonary hypertension: converging evidence using 5- $\mathrm{HT}_{1 \mathrm{~B}}$-receptor knockout mice and the $5-\mathrm{HT}_{1 \mathrm{~B} / 1 \mathrm{D}}$-receptor antagonist GR127935. Circ Res 2001;89:1231-1239.

26 Miller PJ: An elastin stain. Med Lab Technol 1971;28:148-149.

27 Junqueira LC, Montes GS, Krisztan RM: The collagen of the vertebrate peripheral nervous system. Cell Tissue Res 1979;202:453-460.

28 Herget J, Palecek F: Experimental chronic pulmonary hypertension. Int Rev Exp Pathol 1978; 18:347-406.

29 MacLean MR, Deuchar GA, Hicks MN, Morecroft I, Shen S, Sheward J, Colston J, Loughlin L, Nilsen M, Dempsie Y, Harmar A: Overexpression of the 5-hydroxytryptamine transporter gene: effect on pulmonary hemodynamics and hypoxia-induced pulmonary hypertension. Circulation 2004;109: 2150-2155.

30 Tada Y, Laudi S, Harral J, Carr M, Ivester C, Tanabe N, Takiguchi Y, Tatsumi K, Kuriyama T, Nichols WC, West J: Murine pulmonary response to chronic hypoxia is strain specific. Exp Lung Res 2008;34:313-323.

-31 Tang L, Luo B, Patel RP, Ling Y, Zhang J, Fallon MB: Modulation of pulmonary endothelial endothelin B receptor expression and signaling: implications for experimental hepatopulmonary syndrome. Am J Physiol Lung Cell Mol Physiol 2007;292:L1467L1472.

32 Ivy D, McMurtry IF, Yanagisawa M, Gariepy CE, Le Cras TD, Gebb SA, Morris KG, Wiseman RC, Abman SH: Endothelin B receptor deficiency potentiates ET-1 and hypoxic pulmonary vasoconstriction. Am J Physiol Lung Cell Mol Physiol 2001;280:L1040L1048.

33 Ozaki M, Kawashima S, Yamashita T, Ohashi Y, Rikitake Y, Inoue N, Hirata KI, Hayashi Y, Itoh $\mathrm{H}$, Yokoyama M: Reduced hypoxic pulmonary vascular remodeling by nitric oxide from the endothelium. Hypertension 2001; 37:322-327.

34 Steudel W, Scherrer-Crosbie M, Bloch KD, Weimann J, Huang PL, Jones RC, Picard MH, Zapol WM: Sustained pulmonary hypertension and right ventricular hypertrophy after chronic hypoxia in mice with congenital deficiency of nitric oxide synthase 3 . J Clin Invest 1998;101:2468-2477.

35 Fagan KA, Fouty BW, Tyler RC, Morris KG Jr, Hepler LK, Sato K, LeCras TD, Abman SH, Weinberger HD, Huang PL, McMurtry IF, Rodman DM: The pulmonary circulation of homozygous or heterozygous eNOS-null mice is hyperresponsive to mild hypoxia. J Clin Invest 1999;103:291-299.
36 Giaid A, Yanagisawa M, Langleben D, Michel RP, Levy R, Shennib H, Kimura S, Masaki T, Duguid WP, Stewart DJ: Expression of endothelin-1 in the lungs of patients with pulmonary hypertension. N Engl J Med 1993;328:1732-1739.

37 Stewart DJ, Levy RD, Cernacek P, Langleben D: Increased plasma endothelin-1 in pulmonary hypertension: marker or mediator of disease? Ann Intern Med 1991;114:464-469.

- 38 Langleben D, Dupuis J, Langleben I, Hirsch AM, Baron M, Senecal JL, Giovinazzo M: Etiology-specific endothelin-1 clearance in human precapillary pulmonary hypertension. Chest 2006;129:689-695.

39 Naomi S, Iwaoka T, Disashi T, Inoue J, Kanesaka Y, Tokunaga H, Tomita K: Endothelin-1 inhibits endothelin-converting enzyme-1 expression in cultured rat pulmonary endothelial cells. Circulation 1998;97:234-236.

40 Migneault A, Sauvageau S, Villeneuve L, Thorin E, Fournier A, Leblanc N, Dupuis J: Chronically elevated endothelin levels reduce pulmonary vascular reactivity to nitric oxide. Am J Respir Crit Care Med 2005;171: 506-513.

41 Hocher B, Schwarz A, Fagan KA, ThoneReineke C, El-Hag K, Kusserow H, Elitok S, Bauer C, Neumayer HH, Rodman DM, Theuring F: Pulmonary fibrosis and chronic lung inflammation in ET-1 transgenic mice. Am J Respir Cell Mol Biol 2000;23:19-26.

42 De Palma M, Venneri MA, Roca C, Naldini L: Targeting exogenous genes to tumor angiogenesis by transplantation of genetically modified hematopoietic stem cells. Nat Med 2003;9:789-795.

43 De Palma M, Venneri MA, Galli R, Sergi Sergi L, Politi LS, Sampaolesi M, Naldini L: Tie2 identifies a hematopoietic lineage of proangiogenic monocytes required for tumor vessel formation and a mesenchymal population of pericyte progenitors. Cancer Cell 2005;8:211-226.

44 Wang X, Tong M, Chinta S, Raj JU, Gao Y: Hypoxia-induced reactive oxygen species downregulate ETB receptor-mediated contraction of rat pulmonary arteries. Am J Physiol Lung Cell Mol Physiol 2006;290: L570-L578.

45 Schwenke DO, Pearson JT, Mori H, Shirai M: Long-term monitoring of pulmonary arterial pressure in conscious, unrestrained mice. J Pharmacol Toxicol Methods 2006; 53:277-283

-46 Yu AY, Shimoda LA, Iyer NV, Huso DL, Sun $\mathrm{X}, \mathrm{McW}$ illiams R, Beaty T, Sham JS, Wiener CM, Sylvester JT, Semenza GL: Impaired physiological responses to chronic hypoxia in mice partially deficient for hypoxia-inducible factor $1 \alpha$. J Clin Invest 1999;103:691696. 